\title{
Multi-level intervention for HIV/AIDS caring in Indonesian community
}

\author{
Tantut Susanto, Rismawan A. Yunanto, Hanny Rasni, Latifa A. Susumaningrum \\ Department of Community, Family and Geriatric Nursing, Faculty of Nursing, Universitas Jember, Indonesia
}

\begin{abstract}
Treating the spread of human immunodeficiency virus (HIV)/acquired immunodeficiency syndrome (AIDS) needs to be carried out with community participation. Caring community behavior problems require holistic approach for each individual element as well as society related to cultural factors and community contexts, such as norms, relationships, and critical structural factors in strengthening desired outcomes, especially in HIV/AIDS prevention. Some interventions aimed at increasing diversity of participants, and were mostly focused on overcoming individual-level of barriers to research participation. Most of the interventions did not evaluate their effectiveness on increasing the level of trial participation. Overall, there is little focus on interventions aimed at researchers, clinical trials, institutional policy factors, or studies. Therefore, a HIV/AIDS model of intervention is needed that emphasizes the inter-relationship of community elements, with local socio-cultural approaches through multi-level interventions.
\end{abstract}

HIV AIDS Rev 2021; 20, 2: 78-84

DOI: https://doi.org/10.5114/hivar.2021.107217

Key words: LWHA, depression, mental health literacy, help-seeking, knowledge, psychologists.

\section{Introduction}

Human immunodeficiency virus (HIV) and acquired immunodeficiency syndrome (AIDS) as an infectious diseases affecting the whole world, require a holistic and comprehensive approach. The HIV/AIDS transmission phenomenon in a community results in a condition of HIV/AIDS patients' vulnerability and the risk of transmission between individuals within the family and community. Strategies for treating HIV/ AIDS comprehensively, sustainably, or multivariate among a community's sub-system elements, are expected to improve health status of HIV/AIDS patients, and prevent disease transmission based on the socio-cultural approach of community.

The Indonesian Ministry of Health reported that Indonesia's HIV/AIDS challenges considered only $60.7 \%$ of people living with HIV/AIDS (PLWHA) reported, and 70\% of PLWHA received antiretroviral therapy (ARV). However,

Address for correspondence: Tantut Susanto, RN, MN, PHN, PhD, Department of Community, Family and Geriatric Nursing, Faculty of Nursing, Universitas Jember, Jalan Kalimantan 37 Jember, Jawa Timur, Indonesia 68121, e-mail: tantut_s.psik@unej.ac.id

only $33 \%$ received routine ARV treatment, $23 \%$ experienced dropout rates due to ARV and limited health service facilities capable of providing ARV through the care, support, and treatment (CST) program [1]. The CST program for PLWHA can be implemented through community home-based care (CHBC). The CHBC is a form of care provided to HIVinfected people without opportunistic infections, who choose treatment at home, aiming to prevent infection, reduce complications, reduce pain/discomfort, increase self-acceptance in dealing with situations and understand diagnosis, prognosis and treatment, and increase independence to achieve good quality of life (QoL) [2].

The risk of HIV transmission and AIDS treatment involves complex behavior. It is influenced by various elements, including society, knowledge, attitudes, emotions, and perceptions of individual risks to the dynamics of regulation between partners, service accessibility, economic inequality,

Article history:

Received: 25.05.2020

Received in revised form: 30.09 .2020

Accepted: 05.10.2020

Available online: 30.06 .2021
International Journal of HIV-Related Problem

HIV \& AIDS

R e vi e w 
stigmatization of vulnerable groups, and policies, which emphasize HIV as a priority health problem [3-5]. Latest solutions that can be provided in treating HIV/AIDS in the community are to involve additional multi-level factors outside the individual-level of HIV/AIDS, for example, between individuals, networks, institutions, or on structural levels $[6,7]$, as a model of more holistic approach to change in the behavior associated with HIV/AIDS.

Previous studies showed that treating community behavioral problems require a comprehensive approach to each individual and community element linked to cultural factors and community contexts, such as norms, relationships, and structural factors, which are significant in reinforcing desired outcomes, especially in HIV prevention [8-10]. Till date, there has been little research on policy, structural level barriers, and facilitators for recruitment of HIV clinical research. Some interventions aimed at increasing patients' diversity, focusing mainly on overcoming individuallevel obstacles to participation in program. Most of them did not evaluate the effectiveness of interventions on the level increase in program participation. Overall, only a small amount of research has focused on institutional policy factors interventions or community intervention program [11].

Healthcare system for HIV/AIDS in Indonesia is carried out in an integrated manner through the national health service system. First, individuals who are at risk of HIV undergo voluntary and counseling testing (VCT) [12]. If the result is positive, the person receive ARV at primary service [13], i.e., local public health center (PHC). During an ARV program, patients participate in care, support, and medication (CST) service program from public health nurses (PHNs) through a home visit program [2]. During the CST program, if HIV patients experience worsening progress due to decreased CD4+ values or side effects because of ARV treatment, they can be transferred to the first referral hospital before attending level one referral at the teaching hospital.

It is necessary to develop an intervention model for treating HIV/AIDS that prioritizes community's relationship with a local environmental approach. Multi-level interventions allow for a system that further illustrates the varying degrees of influence of individual behavior in the interests of creating an environment, which is beneficial to health promotion [14]. HIV/AIDS as global contagious diseases, require a holistic and comprehensive treatment. The HIV/AIDS transmission phenomenon in the community results in patients' vulnerability to HIV/AIDS and the risk of transmission between individuals within the family and community. The strategy for treating HIV/AIDS challenges in a comprehensive and sustainable (multi-level) manner among sub-system elements in a society, is expected to improve health status of HIV/AIDS patients, and prevent disease transmission based on the socio-cultural approach of the community.

Therefore, the aim of the present study was to create a multi-level intervention model in treating HIV/AIDS challenges in the community through holistic and comprehensive approach, based on Indonesia's community socio-cultural aspects.

\section{Public/community health nursing activities for HIV/ AIDS caring in the community}

Community nurses can play a role in dealing with health problems, both in vulnerable and at health risks groups of patients [15]. As a vulnerable and at health risk group, HIV/AIDS individuals encounter many challenges during ARV programs that require comprehensive management [16]. In Indonesia, the public health service system was developed to deal with health problems, including health office, PHCs, and community [17]. In order to optimize the role of community in Indonesia to be involved in health activities, community resources, such as integrated health service (Posyandu) with active involvement of health workforce [18] were created to improve ARV program and prevent social problems in the community $[19,20]$.

Based on the challenges of treating HIV/AIDS in the community, we are trying to implement a system model in providing care for HIV/AIDS patients called the "multilevel intervention model in the management of HIV/AIDS in the community', which is shown in Figure 1. The flow of activities of PHNs in the care of HIV/AIDS patients from Department of Health is illustrated in Figure 1.

The role of PHNs in the treatment of HIV/AIDS in the community is really needed. PHNs who work in the Department of Health or PHCs can develop several multilevel program activities. Program activities can be designed to start from the Department of Health, non-government organizations (NGOs), PHCs, and hospitals, and applied into the community. The existence of HIV/AIDS patients in the community can be treated by empowering Posyandu's health workforce (voluntary health services), healthcare clinics in the community (clinic health nursing), and family in the care efforts of HIV/AIDS patients in the community. Posyandu can provide HIV/AIDS health education to teach the community about the diseases and its prevention and care. Moreover, Posyandu can be optimized as a place to conduct VCT for HIV/AIDS patients and remote health service and care units. Health workforce can be involved in reporting HIV/AIDS cases in the community. Health cadres can also be engaged in accompanying PHNs in conducting home visits of HIV/AIDS patients. Furthermore, health workforce play a role in providing mental support during ARV treatment.

As seen in Figure 1, the health service can plan, control, and activate HIV/AIDS care programs in the community, and carry out monitoring and evaluation activities at PHCs. Meanwhile, PHCs can provide monthly reports to the health-related office to develop HIV/AIDS care programs in the working area. The health service and PHCs can collaborate with NGOs to provide care for HIV/AIDS patients in the community. Furthermore, the existence of a hospital can be used as a source of reference for the treatment of HIV/ AIDS patients in acute conditions. The hospital can then report to the health service the patients' existence, and after the patient's return from care unit can be obliged to make plans for ongoing repatriation (discharge planning) at PHCs. 


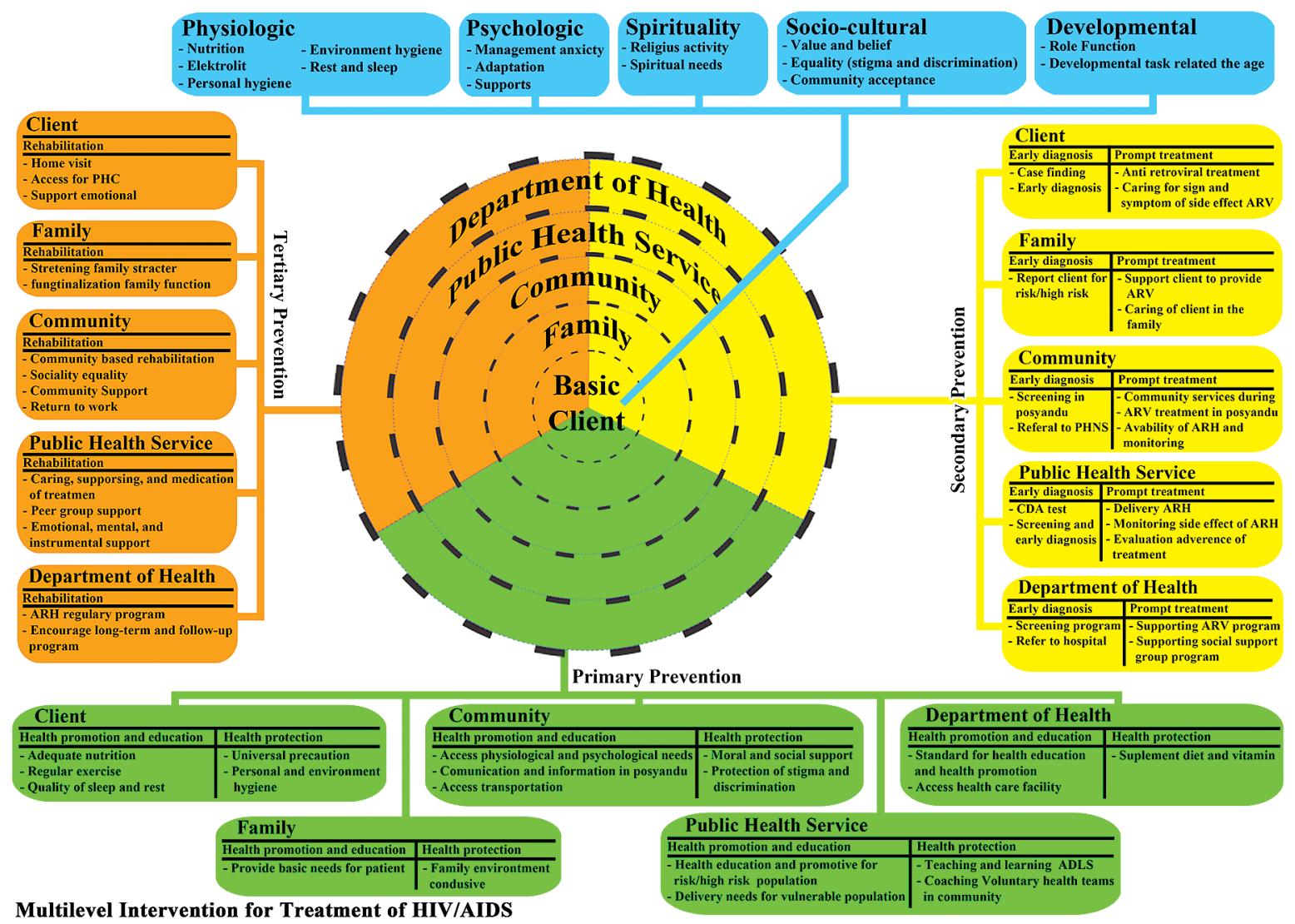

Figure 1. Multi-level intervention model in the management of HIV/AIDS in the community [32]

Additionally, Figure 1 describes PHCs as the primary service center for HIV/AIDS patients in the community to carry out health promotion programs or to implement PHNs programs at PHCs in the community. PHNs at the nursing center can provide nursing intervention to HIV/AIDS patients. Besides, PHCs can perform community empowerment programs at Posyandu through group processes by optimizing health cadres' role to empower the community in caring for HIV/AIDS clients in the community.

Based on Figure 1, nurses in the community can carry out detection and HIV/AIDS case-finding within the family members of the patients. In addition, PHNs at the nursing center can perform family health nursing through a home visit program for HIV/AIDS in the family that can be facilitated and assisted by health cadres. Families with one family member suffering from HIV/AIDS can provide direct care (caring) for this patient, or can use complementary and alternative medicine (CAM) to support the care of HIV/AIDS patients in the community.

\section{Multi-level intervention for HIV/AIDS caring in the community}

To date, there has been little research on policy-level, structural barriers, and facilitators of HIV clinical research recruitment. Some of the interventions aimed at increasing participants' diversity were mostly focused on overcoming individual-level barriers to participation in a research. Most of them did not evaluate the effectiveness of interventions on increasing trials' participation rates. Overall, there is little literature on investigators-targeted interventions, clinical trials, institutional policy factors, or research [21-26]. Therefore, it is necessary to develop an intervention model for treating HIV/AIDS that emphasizes the association of elements in a society using local socio-cultural approach.

Socio-ecological approach can be used as a guide in developing health promotion programs in the community [27]. Components of socio-ecological method can involve the increase of acceptance of HPV vaccine in the community, including intra-personal, inter-personal, institutional, community, and public policies [28]. On the other hand, every element in a society can be optimized in treating HIV/AIDS. To improve taking care of HIV/AIDS challenges in the community, a multi-level intervention model can be developed as an innovation to resolve the challenges based on the socioecological approach. A multi-level approach can be used to address the complexity of HIV problems through interdisciplinary collaboration, to select the most appropriate levels and variables in a particular context. This approach involve measuring social and institutional variables at appropriate 


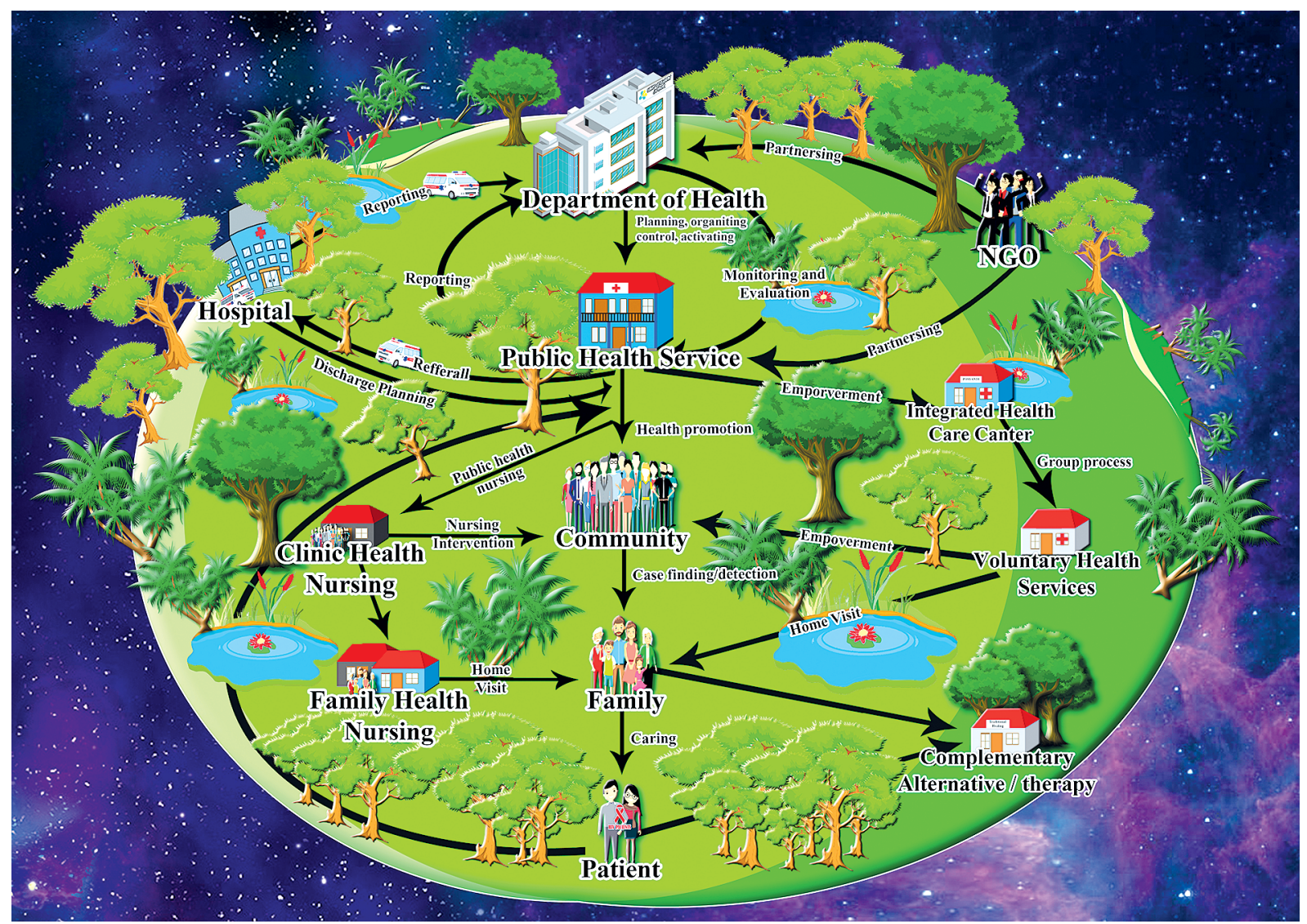

Figure 2. Multi-level interventions for HIV/AIDS patients' care in the community that is carried out in stages within five elements, including health office, PHCs, community, family, and HIV/AIDS patients [32]

levels to ensure that meaningful assessments at various levels are made, and conceptualizing interventions and research concerning theoretical models and mechanisms to facilitate transferability, sustainability, and scalability [29].

In the present study, we tried to described PHNs role in treating HIV/ AIDS patient in the community (Figure 2). Nursing interventions by PHNs can be achieved at multilevel interventions. Figure 2 describes multi-level interventions for HIV/AIDS patients' care in the community that is carried out through five elements, including health office, PHCs, community, family, and HIV/AIDS patients.

As shown in Figure 2, PHNs intervention can be done through 3 levels of prevention, such as primary, secondary, and tertiary prevention $[30,31]$. The circle in Figure 2 is shown in three different colors: green for primary prevention levels, yellow for secondary prevention levels, and orange for tertiary prevention levels. In that circle, the core element is the HIV/AIDS patient, and to the outermost part, the health department. HIV/AIDS patients in the process have basic needs, i.e., physiological needs (nutrition, fluids, personal hygiene, environmental hygiene, and rest/sleep), psychological (anxiety management, adaptation, and social support), spiritual (religious activities and spirituality needs), socio-culture (values and beliefs, fraternity related to stigma and discrimination, and community acceptance), and development (role functions and developmental tasks according to the age stage of patient). Figure 2 indicates the five elements (health department, PHCs, community, family, and patient) using three-level prevention. The implementation of three levels of prevention include primary prevention (health promotion, health education, and health protection), secondary prevention (early diagnosis and early treatment/prompt treatment), and tertiary prevention (rehabilitation). Primary prevention is an activity carried out to prevent disease, disability, and injury. It involves improving health through health education, emphasizing starting healthy lifestyle to increase optimal levels of functioning (proper nutrition, exercise, sleep, recreation, relaxation, not using alcohol, tobacco, and drugs), building healthy personality, counseling, and formation of healthy social environment (Figure 2).

Figure 2 illustrates secondary prevention as an activity related to early detection and treatment. The focus of this prevention is to carry out screening to detect the disease in its first phase. Secondary prevention can be performed by PHNs who observe individuals or groups belonging to the population at risk and identifying risk factors. Subsequently, tertiary prevention is an activity carried out to pre- 
Table 1. Activities for primary, secondary, and tertiary preventions in multi-level intervention for HIV/AIDS caring in community [32]

\begin{tabular}{|c|c|}
\hline Element/Prevention/Intervention & Activities \\
\hline \multicolumn{2}{|l|}{ Department of health office } \\
\hline \multicolumn{2}{|l|}{ Primarily } \\
\hline Health promotion and health education & $\begin{array}{l}\text { Re-arrangement of health promotion and education as a standard } \\
\text { Viability and accessibility of healthcare }\end{array}$ \\
\hline Health protection & Providing nutrition and vitamin needs \\
\hline \multicolumn{2}{|l|}{ Secondary } \\
\hline Early diagnosis & $\begin{array}{l}\text { Screening } \\
\text { Reference to hospital }\end{array}$ \\
\hline Early treatment & $\begin{array}{l}\text { Support for ARV program } \\
\text { Social support for peer-support of HIV/AIDS patients }\end{array}$ \\
\hline \multicolumn{2}{|l|}{ Tertiary } \\
\hline Rehabilitation & $\begin{array}{l}\text { Adherence to ARV treatment } \\
\text { Long-term care support and continuing of program }\end{array}$ \\
\hline \multicolumn{2}{|l|}{ Public health centers } \\
\hline \multicolumn{2}{|l|}{ Primarily } \\
\hline Health promotion and health education & $\begin{array}{l}\text { Health education and promotion for at risk and high-risk population } \\
\text { Referee needs for vulnerable populations }\end{array}$ \\
\hline Health protection & $\begin{array}{l}\text { Education and learning for daily needs } \\
\text { Learning and practice for healthcare in community }\end{array}$ \\
\hline \multicolumn{2}{|l|}{ Secondary } \\
\hline Early diagnosis & $\begin{array}{l}\text { Screening program } \\
\text { Reference to hospital }\end{array}$ \\
\hline Early treatment & $\begin{array}{l}\text { ARV program support } \\
\text { Monitoring for ARV side effects } \\
\text { Evaluation of treatment }\end{array}$ \\
\hline \multicolumn{2}{|l|}{ Tertiary } \\
\hline Rehabilitation & $\begin{array}{l}\text { Continuing for caring, support, and treatment } \\
\text { Peer-support } \\
\text { Support for emotional, mental, and instrumental needs }\end{array}$ \\
\hline \multicolumn{2}{|l|}{ Community } \\
\hline \multicolumn{2}{|l|}{ Primarily } \\
\hline Health promotion and health education & $\begin{array}{l}\text { Identification for physical and psychological needs } \\
\text { Providing communication, information, and education } \\
\text { Access to transportation }\end{array}$ \\
\hline Health protection & $\begin{array}{l}\text { Moral and social support } \\
\text { Protection from stigma and discrimination }\end{array}$ \\
\hline \multicolumn{2}{|l|}{ Secondary } \\
\hline Early diagnosis & $\begin{array}{l}\text { Screening program } \\
\text { Reference to hospital }\end{array}$ \\
\hline Early treatment & $\begin{array}{l}\text { Community support during treatment } \\
\text { ARV treatment } \\
\text { Viability of ARV and monitoring during treatment }\end{array}$ \\
\hline \multicolumn{2}{|l|}{ Tertiary } \\
\hline Rehabilitation & $\begin{array}{l}\text { Community-based rehabilitation } \\
\text { Social equity } \\
\text { Community support } \\
\text { Return to work }\end{array}$ \\
\hline
\end{tabular}


Table 1. Cont.

\begin{tabular}{|c|c|}
\hline Element/Prevention/Intervention & Activities \\
\hline \multicolumn{2}{|l|}{ Family } \\
\hline \multicolumn{2}{|l|}{ Primarily } \\
\hline Health promotion and health education & Providing essential basic needs \\
\hline Health protection & Family environment with comfort and concussive \\
\hline \multicolumn{2}{|l|}{ Secondary } \\
\hline Early diagnosis & Reporting patients at risk and high-risk \\
\hline Early treatment & $\begin{array}{l}\text { ARV therapy support } \\
\text { Patients' treatment at home visits }\end{array}$ \\
\hline \multicolumn{2}{|l|}{ Tertiary } \\
\hline Rehabilitation & $\begin{array}{l}\text { Strengthening family structure } \\
\text { Functionating family functions }\end{array}$ \\
\hline \multicolumn{2}{|l|}{ Client } \\
\hline \multicolumn{2}{|l|}{ Primary } \\
\hline Health promotion and health education & $\begin{array}{l}\text { Health education and promotion for at risk and high-risk populations: } \\
\text { adequate nutrition, routine exercises, good quality of sleep and rest } \\
\text { Referee needs in vulnerable populations }\end{array}$ \\
\hline Health protection & $\begin{array}{l}\text { Learning and education for daily needs: universal precaution, } \\
\text { and personal and environmental hygiene Building capacity for health } \\
\text { staff in community }\end{array}$ \\
\hline \multicolumn{2}{|l|}{ Secondary } \\
\hline Early diagnosis & $\begin{array}{l}\text { Case finding } \\
\text { Early diagnosis }\end{array}$ \\
\hline Early treatment & $\begin{array}{c}\text { ARV program support } \\
\text { Social support for HIV/AIDS patients: signs and symptoms, } \\
\text { and side effects of ARV }\end{array}$ \\
\hline \multicolumn{2}{|l|}{ Tertiary } \\
\hline Rehabilitation & $\begin{array}{l}\text { Home visits } \\
\text { Access to primary health centers } \\
\text { Emotional support }\end{array}$ \\
\hline
\end{tabular}

vent the disease from worsening (chronic) and not causing disability in individuals. Tertiary prevention can be done by rehabilitating the patients, which includes physical, psychological, and spiritual rehabilitation.

Table 1 presents the role of each element responsible for their duties in multi-level intervention program. Each aspect of this system is described in Table 1. Family, cadre, PHNs, PHCs, and health department can manage HIV/AIDS patients in the community. Each element's role was explained as the level of prevention activities for caring HIV/AIDS within the community.

This present study concludes that a multi-level intervention model in handling HIV/AIDS challenges in the community can be used as a holistic and comprehensive HIV/AIDS care program based on the community's socio-cultural approach. This multi-level intervention model was developed based on the interests of sub-system elements of a society by involving the health department, PHCs, PHNs, health cadres, community, and HIV/AIDS patients. The needs of HIV/AIDS patients in the community should be identified and explored holistically, physically, psychologically, socially, economically, and spiritually, based on a local cultural context, with a community nursing approach through the three prevention levels, such as primary, secondary, and tertiary prevention. Therefore, a multi-level intervention model can be developed as an HIV/AIDS patients' service, as primary care in the community, secondary care at referral hospitals, and tertiary services in community-based rehabilitation for each level within the community. Hence, this multi-level model focuses on the role of elements at each level of citizen components in the community to manage HIV/AIDS challenges in order to improve the quality of life of patients, reduce the risk of transmission, and eliminate the stigma related to HIV/AIDS patients in the socio-cultural context of the society in realizing community-based rehabilitation.

\section{Conflict of interest}

The authors have no conflict of interest. 


\section{References}

1. Department of Prevention and Controling Diseases Ministry of Health of Indonesia. Laporan Perkembangan HIV/AIDS dan Penyakit Infeksi Menular Seksual (PIMS) Triwulan II Tahun 2019 (Report of Development of HIV/AIDS and Sxual Transmited Diseases in 2019). Lap Perkemb HIV/AIDS Dan Penyakit Infeksi Menular Seksual Triwulan II Tahun 2019. doi: 10.1055/s-2008-1040325.

2. Rahmawati M. Penanggulangan HIV/AIDS di Indonesia dalam Ancaman RKUHP: Proyeksi Dampak Kriminalisasi Perilaku Beresiko Transmisi HIV/AIDS dalam RKUHP terhadap Penanggulangan HIV/AIDS di Indonesia. Jakarta: Institute for Criminal Justice Reform (ICJR); 2019.

3. Gupta GR, Parkhurst JO, Ogden JA, Aggleton P, Mahal A. Structural approaches to HIV prevention. Lancet 2008; 372: 764-775.

4. Campbell C, Cornish F. Towards a "fourth generation" of approaches to HIV/AIDS management: Creating contexts for effective community mobilisation. AIDS Care 2010; 22 Suppl 2: 1569-1579.

5. Seeley J, Watts CH, Kippax S, Russell S, Heise L, Whiteside A. Addressing the structural drivers of HIV: A luxury or necessity for programmes? J Int AIDS Soc 2012; 15 Suppl 1: 1-4.

6. Albarracin D, Rothman AJ, Di Clemente R, Del Rio C. Wanted: a theoretical roadmap to research and practice across individual, interpersonal, and structural levels of analysis. AIDS Behav 2010; 14: 185-188.

7. Storey D, Figueroa ME. Toward a global theory of health behavior and social change. Obregon/The Handb Glob Heal Commun 2012: 70-94.

8. Coates TJ, Richter L, Caceres C. Behavioural strategies to reduce HIV transmission. Lancet 2009; 372: 669-684.

9. DiClemente RJ, Salazar LF, Crosby RA, Rosenthal SL. Prevention and control of sexually transmitted infections among adolescents: the importance of a socio-ecological perspective - a commentary. Public Health 2005; 119: 825-836.

10. DiClemente RJ, Salazar LF, Crosby RA. A review of STD/HIV preventive interventions for adolescents: sustaining effects using an ecological approach. J Pediatr Psychol 2007; 32: 888-906.

11. Salazar L, DiClemente R. Ecological Approaches in the New Public Health. Barlett Learning, Sudbury 2011. doi: 10.1016/S01406736(80)92737-3.

12. Handayani S, Ratnasari NY, Husna PH, Marni, Susanto T. Quality of Life People Living with HIV/AIDS and Its Characteristic from a VCT Centre in Indonesia. Ethiop J Health Sci 2019; 29: 759-766.

13. Lindayani L, Chen Y, Wang J, Ko N. Complex problems, care demands, and quality of life among people living with HIV in the antiretroviral era in Indonesia. J Assoc Nurses AIDS Care 2018; 29: 300-309.

14. Susanto T, Rasni H, Susumaningrum LA, Yunanto RA, Rahmawati I, Septiyono EA. Model Multilevel Intervensi Penaganan HIV? AID di Komunitas 2019.

15. Susanto T, Bachtiar S, Turwantoko T. Performance of public health nurses and coverage of the nursing care program by community health centers in Jember, Indonesia. Int J Community Based Nurs Midwifery 2019; 7: 161-168.

16. Marni, Nurtanti S, Handayani S, Ratnasari NY, Susanto T. The lived experience of women with HIV/AIDS: a qualitative study. Int J Caring Sci 2018; 11: 1475-1482.

17. Waluyo A, Culbert GJ, Levy J, Norr KF. Understanding HIV-related stigma among Indonesian nurses. J Assoc Nurses AIDS Care 2015; 26: 69-80.

18. Susanto T, Yunanto RA, Rasny H, Susumaningrum LA, Nur KRM. Promoting children growth and development: a community-based cluster randomized controlled trial in rural areas of Indonesia. $\mathrm{Pu}$ blic Health Nurs 2019; 36: 514-524.

19. Ayeno HD, Imer AA. First-line antiretroviral treatment failure and associated factors in HIV patients following highly active antiretroviral therapy at the Shashemene Referral Hospital, Oromia region, Ethiopia. HIV AIDS Rev 2020; 19: 125-131.
20. Sindarreh S, Ebrahimi F, Nasirian M. Stigma and discrimination in the view of people living with human immunodeficiency virus in Isfahan, Iran. HIV AIDS Rev 2020; 19: 132-138.

21. Cook JE, Purdie-Vaughns V, Meyer IH, Busch JTA. Intervening within and across levels: A multilevel approach to stigma and public health. Soc Sci Med 2014; 103: 101-109.

22. Safika I, Levy JA, Johnson TP. Sex work venue and condom use among female sex workers in Senggigi, Indonesia. Cult Heal Sex 2013; 15: 598-613.

23. Cleary PD, Gross CP, Zaslavsky AM, Taplin SH. Multilevel interventions: study design and analysis issues. J Natl Cancer Inst Monogr 2012; 2012: 49-55.

24. White CN, Warner LA. Influence of family and school-level factors on age of sexual initiation. J Adolesc Health 2015; 56: 231-237.

25. Markham CM, Lormand D, Gloppen KM, et al. Connectedness as a predictor of sexual and reproductive health outcomes for youth. J Adolesc Health 2010; 46: S23-41.

26. Gorin SS, Badr H, Krebs P, Das IP. Multilevel interventions and racial/ethnic health disparities. J Natl Cancer Inst Monogr 2012; 2012: 100-111.

27. McDowell T. Applying Critical Social Theories to Family Therapy Practice. Springer International Publishing, New York 2015.

28. Weiner BJ, Lewis MA, Clauser SB, Stitzenberg KB. In search of synergy: Strategies for combining interventions at multiple levels. J Natl Cancer Inst Monogr 2012; 2012: 34-41.

29. Grewe M, Ma Y, Gilbertson A, Rennie S, Tucker J. Women in HIV cure research: multilevel interventions to improve sex equity in recruitment. J Virus Erad 2016; 2: 49-51.

30. Allender JA, Rector C, Warner K. Community Health Nursing Promoting and Protecting the Public's Health. $7^{\text {th }}$ ed. Lippincott Williams \& Wilkins, New York 2010.

31. Anderson ET, McFarlane J. Community as Partner: Theory and Practice in Nursing. $6^{\text {th }}$ ed. Lippincott Williams \& Wilkins, Philadelphia 2011.

32. Susanto T, Rasni H, Susumaningrum LA, Yunanto RA, Rahmawati I, Septiyono, EA. Model Multilevel Intervensi Perawatan Klien HIV/ AIDS di Komunitas. Hak Cipta. Access from: https://pdki-indonesia.dgip.go.id/detail/EC00201979789?type=copyright\&keywor$\mathrm{d}=$ multilevel. 